\title{
Conflict Resolution in Mining Area: An Alternative Strategy of Community Empowerment
}

\author{
Sapar ${ }^{1}$ and Syafruddin ${ }^{2 *}$ \\ 1Program Studi Magister Manajemen, Program Pascasarjana, Universitas Muhammadiyah Palopo \\ 2Program Studi Penyuluh Pertanian, Fakultas Kesehatan, Pertanian dan Kelautan, Universitas Muhammadiyah Palopo
}

\begin{abstract}
ABSTRAK
Penelitian ini menganalisis konflik di sekitar pertambangan dan merumuskan resolusi konflik sebagai strategi pemberdayaan masyarakat di Kabupaten Bombana, Sulawesi Tenggara. Penelitian ini dirancang dengan metode survei deskriptif. Populasi penelitian adalah rumah tangga yang tinggal di desa-desa sekitar wilayah pertambangan, baik di darat maupun di pulau-pulau. Teknik proportional cluster sampling digunakan untuk menentukan sampel. Analisis statistik dilakukan dengan menggunakan statistik deskriptif dan statistik inferensial. Uji statistik inferensial yang digunakan adalah analisis regresi berganda dan uji $\mathrm{t}$ untuk menganalisis perbedaan antara responden di daratan dan pulau-pulau. Hasil penelitian menunjukkan bahwa konflik antara perusahaan dengan masyarakat sekitar pertambangan di Kabupaten Bombana tergolong tinggi. Konflik tersebut meliputi proses pendudukan Sumber Daya Alam (SDA), dominasi perusahaan atas sumber daya alam, dan penanganan dampak negatif. Strategi pemberdayaan masyarakat sekitar pertambangan melalui pengelolaan konflik adalah: (1) Mempercepat penyelesaian konflik yang ada dengan pola musyawarah dan melibatkan semua pihak, termasuk masyarakat setempat, pemerintah, dan penegak hukum setempat. (2) Mendorong perusahaan pertambangan untuk meningkatkan pengelolaan lingkungan yang terkena dampak untuk mencegah kerusakan lingkungan. (3) Meningkatkan pola kerjasama antara perusahaan, pemerintah, dan masyarakat dalam pengelolaan sumber daya alam. (4) Mencegah konflik sosial. Upaya peningkatan pemberdayaan masyarakat sekitar pertambangan dapat dilakukan melalui kerjasama antara pemerintah, perusahaan, dan masyarakat. Pemerintah dan perusahaan memiliki sumber daya yang cukup untuk menginisiasi program pemberdayaan masyarakat sekitar pertambangan di Kabupaten Bombana.
\end{abstract}

Kata kunci: resolusi konflik, pemberdayaan masyarakat

\section{ABSTRACT}

This study analyzes conflicts around mining and formulates conflict resolution as a strategy for community empowerment in Bombana Regency, Southeast Sulawesi. The study was designed with a descriptive survey method. The research population is the householder living in villages around the mining area, both on land and in the islands. The proportional cluster sampling technique does the determination of the sample. Statistical analysis was performed using descriptive statistics and inferential statistics. The inferential statistical test used is multiple regression analysis and t-test to analyze the differences between respondents on the mainland and the islands. The study results indicate that conflicts between companies and communities around mining in Bombana Regency are high. These conflicts include the process of occupation of Natural Resources (SDA), the domination of companies over natural resources, and the handling of negative impacts. Strategies for empowering communities around mining through conflict management are: (1) Accelerating the resolution of existing conflicts with a deliberation pattern and involving all parties, including the local community, government, and local law enforcement. (2) Encouraging mining companies to improve management of the affected environment to prevent environmental damage. (3) Improving the pattern of cooperation between companies, the government, and the community in the management of natural resources. (4) Preventing social conflicts. Efforts to increase the empowerment of communities around mining can be carried out through collaboration between the government, companies, and the community. The government and companies have sufficient resources to initiate community empowerment programs around mining in Bombana Regency.

Keywords: conflict resolution, community empowerment

Citation: Sapar and Syafruddin (2021). Conflict Resolution in Mining Area: An Alternative Strategy of Community Empowerment. Jurnal Ilmu Lingkungan, 19(3), 612-619, doi: 10.14710/jil.19.3.612-619

\section{Introduction}

This article offers a strategy for empowering communities around mining through conflict resolution. The essential thinking of this concept refers to Tabassi et al. (2018) opinion that conflict does not have to be destructive or dysfunctional for the system in which the conflict occurs. Still, that conflict can have positive or beneficial consequences for the system to integrate 
between groups. In addition, Wieviorka (2013) states that conflict is different from a crisis; in fact, both can coexist in social reality. It means that conflict resolution can be an alternative for empowering communities around mining. This article study reveals conflict conditions in mining areas in Southeast Sulawesi Province, Indonesia, precisely in Bombana Regency, and formulates conflict resolution as an alternative to empowering communities around mining.

Communities around mining in Bombana Regency are people who depend on agriculture for their livelihood. Therefore, the existence of mines in their vicinity has a direct impact on agricultural activities. Moreover, it harms the environment, such as the destruction of agricultural land and water sources which are the source of irrigation and daily consumption. This condition triggers conflicts with mining companies. The occurrence of conflict causes the relationship between the community and the company not to work well so that both parties jointly suffer losses because, on the one hand, the company cannot operate and produce optimally. But, on the other hand, the community cannot cooperate with the company to initiate a business or empowerment program.

In line with Tetreault's research (2015) that two things cause conflict in mining areas. First, the appropriation of public resources in the form of mining minerals by companies or outside parties. Second, the exclusion of small farmers and indigenous peoples from their cultural life, water, and land. The same thing was expressed by Tetreault (2015), Collado (2015), Vesco et al. (2021), that conflicts that occur in mining areas are caused by dependence on agriculture and environmental degradation due to mining. In this context, Teijlingen and Hogenboom (2017) questions whether mining is suitable for development? To be relevant, it was also conveyed by Gyan and Ampomah (2016) that mining issues not only have a negative impact on the environment, but also on stakeholders and surrounding communities living near mining areas.

\section{Method}

The study was designed with a descriptive survey method. The study was conducted in Bombana Regency, Southeast Sulawesi Province, from May 2017 to August 2019. The Bombana Regency area consists of mainland and island areas. Mining companies operate in these two areas (Figure 1).

The research population was the householder living in villages around the mining area, both on land and in the islands (Figure 1). The proportional cluster sampling technique does the determination of the sample. Total sample of the study was 182 households, 95 from the mainland and 87 from the islands. The research data was obtained using a questionnaire with interviews and supporting data from key informants obtained by indepth interviews

Data analysis was carried out quantitatively with the support of qualitative data. Statistical analysis was performed using descriptive statistics and inferential statistics. The inferential statistical test used to analyze the dependent and independent variables was multiple regression analysis and t-test to analyze the differences between respondents on the mainland and in the islands.

\section{Result and Discussion}

\subsection{Mining Conflict Condition in Bombana Regency Kabupaten}

The conflict between the company and the community around the mining area in Bombana Regency is categorized as relatively high (Table 1). These conflicts include the process of occupation of Natural Resources (SDA), the domination of companies over natural resources, and the handling of negative impacts.




The natural resource occupation process in the context of this research includes taking over land by mining companies to the community without any compensation or with compensation that is not following the land price that should be. Through intimidation of the community, occupational practices to be willing to give up their land and the seizure of customary land are the primary sources of conflict between the community and the company.

Based on Table 1, the natural resource occupation process, the areas are in the high category. It means that the social conflicts that occur are high due to the occupation process carried out by mining companies. The mining commodity operated by the company in the mainland area is gold mining. The company carries out the land occupation process by buying from the landowner. However, there is community land which is customary land taken over by the company without any compensation. Although the land issue has been resolved, the conflict between the community and the company is still vulnerable because the community is not satisfied with the compensation system implemented by the company. Meanwhile, in the archipelago, the process of natural resource acquisition is categorized as relatively high. The company's land occupation process is considered not following the community's wishes; for example, some residents are forced to sell their land because the company has purchased the surrounding land. Based on the results of the different tests (Table 1), there is a very significant difference between the occupation of natural resources in the mainland area and the island area. The conflict that occurred due to the land occupation in Bombana Regency is in line with research by Bugri and Kumi (2018) that a critical problem faced by the mining industry and society in Ghana is compensation for the loss of land rights in mining activities.

Table 1

Distribution of social conflicts in communities around in mining in 2018-2019

\begin{tabular}{lcccc}
\hline & \multicolumn{3}{c}{ Average score } & $\begin{array}{c}\text { Different test } \\
\text { coefficient } \\
\text { (t-count) }\end{array}$ \\
\cline { 2 - 5 } & Island & Land & Total & $3.64^{* *}$ \\
\hline $\begin{array}{l}\text { Natural } \\
\text { process }\end{array}$ & 84.2 & 93.0 & 88.6 & 1.03 \\
$\begin{array}{l}\text { Dominance over natural resources } \\
\text { Handling negative impacts }\end{array}$ & 88.0 & 89.4 & 88.7 & 1.01 \\
\hline Total social conflict score & 89.4 & 90.4 & 89.9 & 1.01 \\
\hline $\begin{array}{l}\text { Description: Measurement score } 0-100 \\
* *\end{array}$ & 87.2 & 90.9 & 89.1 & \\
\hline
\end{tabular}

The company's dominance over natural resources as a whole is categorized as relatively high. The different tests show no significant difference between the company's dominance in the mainland and the archipelago. Mine management processes, from land mapping, surveys to environmental management, involve little community. Even many residents do not know the boundaries of the mining area that belongs to the company. Since the beginning of exploration, community involvement is vital so that the surrounding community knows about mining operations around them, especially regarding area boundaries and environmental management. The existence of community involvement can reduce social conflicts that occur. The company can design a program with the community on management mechanisms that allow the community to be involved, starting from land surveys, acquisitions to environmental management designs, pre-production, and post-production, with the community empowerment program plan to implement. The mechanism of community involvement can minimize the company's dominance, which tends to trigger conflict and create public trust in the company to avoid disputes between the company and the community. Budhyono (2008) stated that historically the relationship between the mining industry and the community had had severe problems (conflicts). This conflict is caused by the company operating in an area that has not yet gained social legitimacy, causing significant damage and leaving the site when its economic value has been exhausted.

The handling of negative impacts is terrible, both on land and on islands (Table 1). Overall, the handling of adverse effects is not significantly different between the mainland and the islands. Negative impacts arising from the company's operations occur in adverse effects on the physical and social environment. The company's activities cause damage to land, forests, water, and air pollution in the physical environment. Nickel mining activities in the archipelago cause land and forest damage because soil containing nickel is dredged to several meters. In addition, the process of transferring mining materials to temporary shelters also creates dust during the dry season. The dust disturbance is quite felt by residents who live close to the mining area. In the rainy season, there is an overflow of river water which 
causes flooding because the water channel is disturbed by the runoff of mud that covers the river body. It pretty much concerns the activities of residents who live around the mining area. Meanwhile, the negative impact on the social environment is in health problems for residents, especially in the dry season due to dust that arises from moving mining materials. The handling of negative impacts by mining companies in the archipelago is carried out in repairing waterways and providing cash funds to residents. Activities undertaken to minimize the appearance of dust is to do watering. However, according to residents, these efforts are not significant enough to reduce the appearance of dust around them.

The negative impacts that arise from mining activities in mainland areas are different from those in the islands. It is due to the different types of mines managed. On the mainland, the negative impact felt by residents is the contamination of river water, and irrigation canals by gold processing waste carried out by the company. Even though the company stated that it already has a sewage treatment plant system, residents who use river water feel skin irritation if they use river water for bathing. According to residents, the handling of negative impacts by mining companies in mainland areas is not optimal. There is even no plan that is specifically intended to handle complaints from residents who use river water. The company only provides financial assistance managed directly by the local village government and includes services for infrastructure repairs. The handling of negative impacts by companies in the two research locations has not focused on the consequences experienced by the community. Instead, it triggers the emergence of conflicts between mining companies and the people who live around the mining area.

\subsection{The Effect of Social Conflict on the Adaptive Competence Level of Communities around Mining}

Social conflict has a significant adverse effect on the level of community adaptive competence (Table 2), namely social conflict from the natural resource occupation process and the handling of negative impacts. It shows that the high level of social competition impacts the community's low level of adaptive competence around mining in the Bombana Regency.

Table 2. The value of the social conflict regression on the level of adaptive competence of communities around mining in Bombana Regency in 2018

Social conflict

\begin{tabular}{ll}
\hline Natural resources occupation process & $-0.618^{* *}$ \\
Dominance over natural resources & -0.109 \\
Handling negative impacts & $-0.472^{* *}$ \\
\hline Description: ${ }^{* *}$ Significant at $\alpha \leq 0.01$ &
\end{tabular}
community adaptive competence
Value of the regression coefficient on the level of

the research location include water pollution, land damage, and the appearance of dust that interferes with public health. Thus, mine processing causes negative impacts that are quite damaging to both the physical and social environment, especially public health. Conflicts due to adverse effects can disturb both parties, both the community and the company. However, mutually beneficial relationships can be built by managing the negative impacts caused by mining company operations.

Conflicts in mining areas represent the economic injustice and access to resources experienced by the surrounding community. The community considers that the exploration area is their familiar territory or hometown. On the other hand, the company believes that the authority it receives through mining permits feels that it has the right to carry out exploration as much as possible for its economic interests. This asymmetrical interest has the potential to become a conflict that has a detrimental impact on all parties. The potential conflict management in the mining environment has been influenced by three main actors: the company, the community around the mine, and the government 
(Sumardjo 2015). The results of Tetreault's research (2015) show that two things cause conflict in mining areas. First, the appropriation of public resources in the form of mining minerals by companies or outside parties. Second, the exclusion of small farmers and indigenous peoples from their cultural life, water, and land.

\subsection{Effect of Social Conflict on Empowerment Dynamics}

Social conflict has an authentic negative effect on the dynamics of community empowerment around mining in the Bombana Regency (Table 3). It means that the high social disputes between mining companies and the community impact the low dynamics of community empowerment.

The natural resource occupation process carried out by mining companies triggers disputes between landowners and companies. Some dispute cases can be resolved amicably through a compensation mechanism agreed upon by both parties. Still, some other issues cannot be resolved, causing open disputes between the community and the company. The occupation process also directly results in the transfer of land ownership from the community to the company. For residents who are farmers, the land is their primary source of livelihood, so if the land is sold, they lose their source of income and have to look for other sources.

The company's dominance over natural resources has a real effect on the dynamics of community empowerment. It means that the company's high authority over natural resources reduces the dynamics of community empowerment around mining in the Bombana Regency. The domination of the company referred to in this case is the company's control over all natural resources in the mining area, including environmental management, without involving the surrounding community. Ideally, the mine management and all the resources in the mining area involve the community so that residents can still take advantage of the environmental potential that exists in the area, such as vacant land. With this pattern, residents who have sold their land can still use land that the company has not processed. Although it is temporary, it helps people who have lost their land before gaining new livelihoods.

Handling negative impacts has real effects on the dynamics of community empowerment. It means that the poor handling of the adverse effects caused by company activities reduces the dynamics of community empowerment around mining in the Bombana Regency. It is because company activities have a direct impact on both the physical and social environment. Handling adverse effects aims to reduce or eliminate harmful risks, not to impact social and environmental conditions.

Overall, social conflicts cause losses and reduce the dynamics of community empowerment around mining areas in the Bombana Regency. It is in line with Tetreault's (2015) research that two things cause conflicts in mining areas. First, the appropriation of public resources in the form of mining minerals by companies or outside parties. Second, the exclusion of small farmers and indigenous peoples from their cultural life, water, and land. According to Sumardjo (2015), conflicts in mining areas represent economic injustice and access to resources experienced by the surrounding community. The community considers that the exploration area is their familiar territory or hometown. On the other hand, the company believes that the authority it receives through mining permits feels that it has the right to carry out exploration as much as possible for its economic interests. This asymmetrical interest has the potential to become a conflict that has a detrimental impact on all parties. Thus, the management of the potential conflicts in the mining environment is influenced by three main actors: the company, the community around the mine, and the government.

Table 3 The value of the social conflict regression coefficient on the dynamics of community empowerment around mining in Bombana Regency in 2018

\begin{tabular}{lc}
\hline \multicolumn{1}{c}{ Social conflict } & $\begin{array}{c}\text { Value of the regression coefficient on } \\
\text { the dynamics of empowerment }\end{array}$ \\
\hline Natural resources occupation process & $-0.69^{* *}$ \\
Dominance over natural resources & $-0.16^{* *}$ \\
Handling negative impacts & $-0.14^{* *}$ \\
\hline Description: ${ }^{* *}$ Significant at $\alpha \leq 0.01$ &
\end{tabular}

\subsection{Conflict Management to Improve Empowerment Dynamics}

The results showed that the social conflict between the community and mining companies in Bombana
Regency was high. The high level of conflict affects the low dynamics of community empowerment. According to Suharto (2005), conflict can be defined as a conflict of power and interest between one group and another in the process of competing for relatively limited social 
resources (economic, political, social, cultural). The forms of conflict in communities around mining in Bombana Regency are generally land conflicts, natural resource control, and conflicts due to poor handling of the negative impacts caused by company activities.

According to Sumardjo (2015), conflicts in mining areas represent economic injustice and access to resources experienced by the surrounding community. The community considers that the exploration area is their familiar territory or hometown. On the other hand, the company believes that the authority it receives through mining permits feels that it has the right to carry out exploration as much as possible for its economic interests. This asymmetrical interest has the potential to become a conflict that has a detrimental impact on all parties.

In general, several forms of conflict that occur around mining in Southeast Sulawesi, according to Hafid (2015), are (1) conflicts between companies holding IUP (Mining Business Permits) and indigenous peoples because they are considered to have seized customary/ancestral territories. (2) Conflicts between companies holding IUP and community landowners because they are considered to have taken over their plantation and livestock land. (3) Conflicts between companies holding IUP and settlement communities around the mining area because they are considered to pollute water sources, rivers, and the waters where they look for/raise fish. (4) Conflicts between companies holding IUPs with local governments and settler communities around mining areas because they are considered conducting exploration outside the area of control permits by encroaching on protected forests. Other conflicts with economic nuances: (1) conflicts between one company holding a Mining Business Permit (IUP) and another company due to overlapping land, and (2) conflict between shareholders in a company holding an IUP.

Conflict management should be one of the main priorities, especially by the government and companies. Although in this case, the community cannot be forgotten to resolve the conflicts that occur. According to Sumardjo (2015), the management of potential matches in the mining environment is influenced by three main actors: the company, the community around the mine, and the government. Based on observations at the research site, conflicts between companies and the community always involve the government, companies, and the community. However, the community felt that there was intimidation in every conflict resolution because of security forces. Therefore, the community accepted the conflict resolution solutions offered by the company.

According to Sukirman (2014), conflict situations related to mining problems can develop into three possible alternative solutions: consensus, trading, and power. Agreement occurs when the community living in the mining area and the local government agree to sit down together to discuss mining management with various advantages and disadvantages for the environmental conditions and the communities around the mine to be understood and accepted together. Trading, if the people who inhabit the mining area are willing to cooperate with the local government in mining management with specific contracts and compensation (benefits for the community), not only profits for the authorities but also the government. Finally, if the government imposes its will in mining management with a repressive or violent approach to the mining area's people.

\subsection{Strategy for community empowerment around mining through conflict management}

Social conflict is a condition that always occurs in mining areas. It harms people's lives. Based on the analysis of the effect of social conflict on adaptive competence and dynamics of empowerment, it is found that social conflict has real effects on the low level of adaptive competence and dynamics of community empowerment. The majority of communities around mining in Bombana Regency are farmers. When mining companies arrived and started operating, many residents lost their land. In contrast, some residents who still own land feel the impact of environmental damage due to a lack of water sources for irrigation and pollution. According to Tetreault (2015) conflict is driven more by dependence on agriculture than by the use of other natural resources. It happens because the community is a farmer with a high reliance on agricultural products to meet their daily needs.

Government intervention is significant to minimize conflicts that occur around mining. The government has formal authority to implement policies that must be complied with by mining companies operating in its territory. Hegre and Nygard (2015) suggest that good governance is crucial to reduce the risk of conflict. Governments with good governance can speed up conflict ending. For governments with poor governance, the conflict resolution process takes longer.

Conflict can also hinder an activity, including empowerment programs. Lawson and Kearn (2010) emphasize that community stability or cohesiveness is an essential factor in empowerment. More stable areas are easier to manage and, in many places, potentially offer more opportunities for empowerment. Therefore, before the conflict spreads and becomes more open, intensive communication from all stakeholders must be clarified and resolved immediately. In addition, differences in socio-cultural characteristics that exist in the community are also important in managing conflicts that occur. As stated by Gomez and Taylor (2018) that community culture influences conflict resolution.

Based on the description above, can be formulated strategies for community empowerment around mining through conflict management, namely:

(1) Accelerating the resolution of existing conflicts with a deliberation pattern and involving all 
parties, including the local community, government, and local law enforcement officers

(2) Encouraging mining companies to improve management of the affected environment to prevent environmental damage

(3) Improving the pattern of cooperation between companies, the government, and the community in the management of natural resources

(4) Preventing social conflicts.

The occurrence of conflicts between communities and mining companies in the Bombana Regency is caused by land occupation that is detrimental to the community, the company's dominance over natural resources, and the poor handling of the negative impacts caused by mining activities. The number of problems between the company and the community that is not resolved triggers a prolonged conflict between the community and the company. For example, there was the blocking of roads traversed by transport vehicles and the destruction of heavy equipment belonging to mining companies. Based on interviews, mining companies have never held consultations with the community to resolve conflicts. Therefore, in collaboration with the Bombana Regency government, mining companies, law enforcement officers, and community leaders can resolve disputes quickly through a mechanism of consultation with the community. As suggested by Larsson (2016), successful conflict resolution is more effectively carried out together in an informal way and with consideration of local wisdom. Conflict prevention and resolution strategies and practices require a learning process and the integration of external knowledge and local experience, a responsible bureaucracy, transparent procedures, and an accessible justice system.

Another problem that is often a source of conflict between communities and mining companies in the Bombana Regency is environmental management and pollution. Minerba (mineral and coal) laws and regional regulations have regulated mining companies to carry out ecological management in rehabilitating ex-mining land and managing waste not to pollute the environment. However, based on interviews and observations at the research site, most mining companies in Bombana Regency do not rehabilitate ex-mining land. Therefore, the local government of the Bombana Regency can encourage and supervise mining companies to carry out environmental management. A sanction mechanism can be applied if the mining company does not carry out land rehabilitation following applicable laws and regulations.

The pattern of cooperation between companies, the government, and the community in terms of natural resource management can be carried out so that the community can benefit from the natural resources around them. For example, the government facilitates the community to participate in mining businesses through community mining schemes in partnership with mining companies. Other cooperation can also be carried out between mining companies and the surrounding community, for example, partnering with the community to provide logistics needed by the company. However, such a pattern of cooperation based on observations and interviews at the research site has not been carried out. The need for a collaborative strategy to manage natural resources is also recommended by Ratner et al. (2017) to strengthen collective action institutions in the natural resource sector and enable more equitable engagement by marginalized groups in dialogue and negotiations on resource access and use.

Conflicts between mining companies and communities in Bombana Regency can be prevented by implementing community empowerment programs. The local government of the Bombana Regency can encourage mining companies to implement empowerment programs as mandated by local laws and regulations. Empowerment programs that are implemented should not only focus on infrastructure development but also be accompanied by human resources development by providing training to improve skills and providing assistance for business actors ranging from business management to financial administration to marketing.

\section{Conclusion and suggestion}

\subsection{Conclusion}

Conflicts that occur between companies and communities around mining in Bombana Regency are high. These conflicts include the process of occupation of Natural Resources (SDA), the domination of companies over natural resources, and the handling of negative impacts. Strategies for empowering communities around mining through conflict management are: (1) Accelerating the resolution of existing conflicts with a deliberation pattern and involving all parties, including the local community, government, and local law enforcement. (2) Encouraging mining companies to improve management of the affected environment to prevent environmental damage. (3) Improving the pattern of cooperation between companies, the government, and the community in the management of natural resources. (4) Preventing social conflicts.

\subsection{Suggestion}

Efforts to increase the empowerment of communities around mining can be carried out through collaboration in partnership between the government, companies, and the community. The government and companies have sufficient resources to initiate community empowerment programs around mining in Bombana Regency.

\section{DAFTAR PUSTAKA}

Budhyono, H.T, (2008), Pengelolaan Strategi Pengembangan Masyarakat pada Industri Tambang untuk Keberlanjutan Bisnis Jangka Panjang dan Mendukung Pembangunan 
Berkelanjutan (Studi Kasus: Program Pengembangan Masyarakat PT Freeport Indonesia). National Conference on Management Research Prosiding, 45-53.

Bugri, J.T., Kumi, S., (2018), Dynamics of Community Perceptions, Common Resources and Compensation Practices in Mining the Case of Newmont Ghana Gold Ltd at Ahafo. International Journal of the Commons, 12(1), 125.

Collado, P.A., (2015), Social Conflict in Argentina Land, Water, Work. Latin American Perspectives, 42(2), 125-141.

Gomez, C., and Taylor, K.A., (2018), Cultural Differences in Conflict Resolution Strategies: A US-Mexico Comparison. International Journal of Cross-Cultural Management, 18(1), 33-51.

Gyan, C., and Ampomah, A., O., (2016), Effects of Stakeholder Conflicts on Community Development Projects in Kenyase, Sage Open, 6(1), 1-6.

Hafid, A., (2015), Konflik Sara di Wilayah Pertambangan (Kasus Sulawesi Tenggara), Article, 1-12.

Hegre, H., Nygard, H.M., (2015), Governance and Conflict Relapse. Journal of Conflict Resolution, 59(6), 984-1016.

Larsson, J., (2016), Conflict-Resolution Mechanisms Maintaining an Agricultural System. Early Modern Local Courts as an Arena for Solving Collective-Action Problems within Scandinavian Civil Law, International Journal of the Commons, 10(2), 1100-1118.

Ratner, B.D., Dick, R.M., Hellin, J., Mapedza, E., and Unruh, J., (2017), Addressing Conflict through Collective Action in Natural Resource Management. International Journal of the Commons, 11(2), 877-906.
Suharto, E., (2005), Konflik Sosial, Masyarakat Multikultural dan Modal Kedamaian Sosial dalam Isu-Isu Tematik Pembangunan Sosial: Konsepsi dan Strategi, Badan Pelatihan dan Pengembangan Sosial Departemen Sosial Republik Indonesia, Jakarta.

Sukirman, A., (2014), Penanganan Konflik Tambang di Bima Berdasarkan Teori Sosial dan Konflik, Article, 1-15.

Sumardjo, (2015), Analisis Pengelolaan Potensi Konflik di Masyarakat Sekitar Tambang Berbasis Ketahanan Pangan dan Energi (Kasus Tambang Emas di Jawa Barat dan Tambang Batubara di Kalimantan Selatan), Artikel, 1-2.

Tabassi, A.A., Abdullah, A., and Bryde, D.J., (2018), Conflict Management, Team Coordination, and Performance Within Multicultural Temporary Projects: Evidence From the Construction Industry, Project Management Journal, (50)1, 101-114.

Teijlingen, K.V., and Hogenboom, B., (2017), Debating Alternative Development at the Mining Frontier: Buen Vivir and the Conflict Around El Mirador Mine in Ecuador, Journal of Developing Societies, 32(4), 382-420.

Tetreault, D., (2015), Social Environmental Mining Conflicts in Mexico, Latin American Perspectives, 42(5), 48-66.

Vesco, P., Kovacic, M., Mistry, M., and Croicu, M., (2021), Climate Variability, Crop and Conflict: Exploring the Impacts of Spatial Concentration in Agricultural Production, Journal of Peace Research, 58(1), 98-113.

Wieviorka, M., (2013), Social Conflict. Current Sociology Review, 61(5-6), 696-713 